\title{
Alternatif Pemanfaatan Penyandang Disabilitas bagi Kegiatan Pertanian di Desa Sidoharjo, Kecamatan Jambon, Kabupaten Ponorogo
}

\author{
Rezza Perdana Al Hanif dan Eko Budi Santoso \\ Departemen Perencanaan Wilayah dan Kota, Fakultas Teknik Sipil dan Perencanaan \\ Institut Teknologi Sepuluh Nopember (ITS) \\ e-mail: eko_budi@urplan.its.ac.id
}

\begin{abstract}
Abstrak-Desa Sidoharjo termasuk desa yang memiliki fenomena yang cukup langka di dalam kehidupan pada umumnya. Sekitar 3,3\% dari total penduduk atau 210 orang merupakan penyandang disabilitas terdapat di desa tersebut dengan kondisi serta permasalahan yang beragam. Pertanian menjadi sektor dominan yang diusahakan di Desa Sidoharjo, namun penyandang disabilitas masih sangat sedikit yang diberdayakan. Pertanian selama ini juga masih belum dapat mengakomodasi secara utuh segala potensi dari penyandang disabilitas di Desa Sidoharjo. Oleh karena itu, penelitian ini bertujuan untuk merumuskan alternatif pemanfaatan penyandang disabilitas bagi kegiatan pertanian di Desa Sidoharjo. Dalam penelitian ini digunakan berbagai tinjauan teori yang berkaitan dengan pertanian, kegiatan-kegiatan pertanian, dan penyandang disabilitas. Sedangkan untuk mencapai tujuan penelitian, dilakukan tiga tahapan analisa yaitu mengidentifikasi potensi pertanian di Desa Sidoharjo menggunakan analisis content, menganalisa kemampuan dan kebutuhan penyandang disabilitas dalam sektor pertanian di Desa Sidoharjo menggunakan analisis content, dan menentukan alternatif pemanfaatan penyandang disabilitas bagi kegiatan pertanian di Desa Sidoharjo menggunakan analisis triangulasi. Berdasarkan hasil penelitian, alternatif pemanfaatan penyandang disabilitas antara lain: membentuk jaringan kerja untuk penyandang disabilitas, melakukan habilitasi dan rehabilitasi kepada penyandang disabilitas, melakukan resosialisasi kepada masyarakat, dan pemberian pembinaan dan pelatihan kepada penyandang disabilitas dalam bidang pertanian.
\end{abstract}

Kata Kunci-Pengembangan Pertanian, Kegiatan Pertanian, Penyandang Disabilitas.

\section{PENDAHULUAN}

$\mathrm{K}$ ABUPATEN Ponorogo merupakan salah satu kabupaten di Indonesia yang bergantung pada sektor pertanian. Pertanian (masuk dalam jenis lapangan usaha pertanian, kehutanan, dan perikanan) menyumbang 31,65 \% dari total keseluruhan PDRB Kabupaten Ponorogo. Dalam kurun tahun 2013 - 2015, sektor pertanian juga menunjukkan pertumbuhan yang cukup baik yaitu rata-rata $11,23 \%$ per tahun. Berdasarkan survei angkatan kerja nasional, sebanyak 52,6 \% penduduk Kabupaten Ponorogo bekerja pada sektor pertanian (masuk dalam jenis lapangan usaha pertanian, kehutanan, dan perikanan). Dengan ini, dapat diartikan bahwa peningkatan kesejahteraan penduduk di Kabupaten Ponorogo akan sangat bergantung pada pertumbuhan sektor pertanian [1].]

Produksi pertanian Kabupaten Ponorogo memiliki jumlah yang sangat besar. Pertanian Kabupaten Ponorogo dalam jenis tanaman pangan pada tahun 2016 memproduksi 518.566 ton ubi kayu, 479.839 ton padi, 263.266 ton jagung, 21.948 ton kedelai. 1.958 ton kacang tanah, 1.652 ton kacang hijau, dan 1.192 ton ubi jalar. Beberapa komoditas tanaman sayur-sayuran yang memiliki produksi tinggi pada tahun 2016 adalah wortel dengan jumlah produksi 7.694 ton, buncis dengan jumlah produksi 7.266 ton, petai dengan jumlah produksi 5.181 ton, kubis dengan jumlah produksi 4.519 ton, dan bawang daun dengan jumlah produksi 3.784 ton. Sedangkan komoditas buah-buahan menghasilkan 39.982 ton pisang, 8.727 ton jeruk keprok, 7.987 ton nangka, 4.826 ton melon, dan 4.277 ton pepaya.

Salah satu desa yang mayoritas masyarakatnya bergerak dalam bidang petanian adalah Desa Sidoharjo. Namun, ada fenomena yang cukup unik dengan kondisi demografi di desa ini yaitu memiliki jumlah penyandang disabilitas yang cukup banyak. Bahkan Desa Sidoharjo merupakan desa yang memiliki jumlah penyandang disabilitas paling banyak dibandingkan desa-desa lain di Kecamatan Jambon. Penyandang disabilitas memiliki proporsi sebanyak 3,3\% dari total jumlah penduduk di Desa Sidoharjo atau 210 orang dari total penduduk sejumlah 6.376 orang dengan rincian 9 tunanetra, 28 tunarungu, 11 tunawicara, 5 tuna rungu wicara, 12 tuna daksa, 7 tunagrahita, 101 cacat mental, 37 cacat ganda. Namun, berdasarkan hasil survei primer, tidak ada penyandang tunadaksa di Desa Sidoharjo. Banyaknya penyandang cacat mental di desa ini menurut Dinas Kesehatan Kabupaten Ponorogo disebabkan oleh kekurangan yodium di daerah tersebut. Selain itu, diasumsikan juga bahwa penyebabnya adalah kawin sedarah, kemiskinan, serta memakan makanan yang kurang bergizi seimbang dalam rentang waktu yang cukup lama. Kondisi ini tidak lepas 
dengan jumlah KK yang merupakan keluarga pra sejahtera sebanyak $30 \%$ dari jumlah KK yang ada [2].

Sedikit sekali jumlah penyandang disabilitas yang diberdayakan dalam sektor pertanian. Mayoritas penyandang disabilitas tersebut umumnya membantu dalam mencari rumput untuk hewan ternak milik keluarga penyandang disabilitas tersebut. Beberapa penyandang disabilitas (dalam jumlah yang sangat sedikit) diberdayakan saat proses panen dan proses membajak sawah. Pemerintah sendiri dalam penyaluran bantuan, masih cenderung kepada pelatihan daily life activity, kerajinan tangan, dan sektor-sektor yang selama ini masih dianggap masih bisa diusahakan untuk penyandang disabilitas. Sedangkan penanganan dan pengembangan penyandang disabilitas pada sektor pertanian masih belum dilakukan.

Sektor pertanian menjadi penting bagi peningkatan kondisi perekonomian penyandang disabilitas di Desa Sidoharjo dengan beberapa alasan. Pertama, solusi yang jamak ditawarkan pemerintah kepada penyandang disabilitas berupa pembuatan kerajinan tangan tidak memberikan dampak peningkatan pendapatan yang signifikan sehingga kemiskinan tetap terjadi di keluarga penyandang disabilitas. Kedua, mayoritas penduduk di Desa Sidoharjo berprofesi sebagai petani sehingga penyandang disabilitas tentu sudah tidak asing dengan kegiatan-kegiatan dalam bidang pertanian. Ketiga, salah satu penyebab yang menjadi indikasi utama tejadinya kedisabilitasan di Desa Sidoharjo adalah kekurangan gizi karena keterbatasan jenis makanan yang dapat dikonsumsi sehingga sektor pertanian yang menjadi pemasok pangan utama sangat berperan dalam memutus mata rantai penyebab kedisabilitasan.

Kegiatan pertanian tentu bukan kegiatan yang ringan untuk dijalankan apalagi dalam kondisi penyandang disabilitas yang serba kekurangan. Kedisabilitasan tersebut tentu menghambat penyandang disabilitas dalam bekerja secara optimal dalam kegiatan pertanian. Namun dengan segala keterbatasannya, masih terdapat beberapa penyandang disabilitas di Desa Sidoharjo yang bergerak dalam bidang pertanian, walaupun dalam kenyataannya banyak penyandang disabilitas yang masih belum dapat meningkatkan taraf derajat hidupnya secara signifikan.

Berdasarkan pemaparan masalah diatas untuk memberdayakan penyandang disabilitas maka dibutuhkan alternatif pemanfaatan penyandang disabilitas bagi kegiatan pertanian di Desa Sidoharjo. Alternatif pemanfaatan penyandang disabilitas ini nantinya digunakan untuk mengoptimalkan potensi penyandang disabilitas dalam kegiatan pertanian sehingga dapat terlepas dari kondisi kemiskinan dan ketidakmandirian.

\section{METODE PENELITIAN}

\section{A. Jenis dan Pendekatan Penelitian}

Pendekatan yang digunakan dalam penelitian ini adalah pendekatan rasionalistik. Jenis penelitian dalam penelitian ini adalah penelitian kualitatif [3].

\section{B. Variabel Penelitian}

Variabel penelitian yang digunakan untuk mengidentifikasi potensi pertanian di Desa Sidoharjo antara lain produk pertanian, teknologi pertanian, kegiatan budidaya, kegiatan panen, dan kegiatan pascapanen.

Variabel penelitian yang digunakan untuk analisa kemampuan dan kebutuhan penyandang disabilitas dalam kegiatan pertanian di Desa Sidoharjo adalah penyebab kedisabilitasan, kegiatan sehari-hari penyandang disabilitas, kemampuan belajar, kemampuan bekerja dalam bidang pertanian, kebutuhan umum penyandang disabilitas, dan kebutuhan pertanian penyandang disabilitas.

\section{Metode Penentuan Sampel}

Pengambilan sampel dalam penelitian ini menggunkan metode non probability sampling. Metode ini merupakan suatu teknik pengambilan sampel yang tidak didasari oleh peluang. Teknik non probability sampling yang digunakan dalam penelitian ini melalui stakeholder analysis.

Terdapat tiga kelompok responden dalam penelitian ini. Pertama, kelompok governance terdiri atas Dinas Pertanian Kabupaten Ponorogo. Kedua, kelompok private sector terdiri atas LSM Sidowayah Bangkit dan kelompok tani di Desa Sidoharjo. Ketiga, kelompok civil society terdiri atas penyandang tunanetra, penyandang tunarungu wicara, dan penyandang tunagrahita.

\section{Mengidentifikasi Potensi Pertanian di Desa Sidoharjo}

Analisis data adalah proses mengatur urutan data, mengorganisasikanya ke dalam suatu pola, kategori, dan satuan uraian dasar. Setelah data tersebut diorganisasikan, maka agar memudahkan untuk menjawab tujuan penelitian dan mengambil kesimpulan. Dalam menjawab tujuan penelitian diperlukan teknik analisis yang tepat untuk mengolah data yang telah diperoleh [4].

Analisis Content digunakan untuk mengidentifikasi potensi-potensi pertanian di Desa Sidoharjo. Tahapan-tahapan dalam analisis content adalah sebagai berikut: [5]

1. Tahapan awal dari content analysis adalah pengunitan. Pengunitan adalah upaya untuk mengambil data yang dibutuhkan sesuai dengan kepentingan penelitian yang dapat diobservasi lebih lanjut.

2. Tahapan kedua adalah peneliti melakukan sampling. Pembatasan jumlah stakeholder ditentukan melalui stakeholder analysis dimana telah mewakili karakteristik populasinya.

3. Tahapan ketiga adalah perekaman atau pengkodean. Tahap ini berguna untuk menjembatani teks yang telah diunitkan dengan peneliti. Pengkodean akan dipilah berdasarkan karakteristik unit, menyesuaikan, kemudian ditandai pada setiap transkrip, lalu dimasukkan ke dalam tabel/matriks analisis.

4. Tahapan keempat adalah pemahaman. Tahap ini dilakukan untuk melihat relevansi analisis. Selain itu, tahap ini digunakan sebagai jembatan untuk tahap 
penarasian.

5. Tahapan terakhir adalah penarasian. Pada tahap ini dilakukan abstraksi dari hasil analisis yang sudah dilakukan.

Setelah melakukan analisis maka diketahui potensi produk pertanian, potensi teknologi pertanian, dan potensi kegiatan-kegiatan pertanian di Desa Sidoharjo. Potensi produk pertanian yang dibudidayakan oleh penyandang disabilitas di Desa Sidoharjo menjadi masukan untuk menuntukan kegiatan-kegiatan pertanian yang sesuai dengan produk atau komoditas pertanian tersebut. Selanjutnya, kegiatan-kegiatan pertanian yang sesuai tersebut menjadi masukan atas kemampuan bekerja penyandang disabilitas dalam sektor pertanian.

\section{E. Menganalisia Kemampuan dan Kebutuhan Penyandang} Disabilitas dalam Sektor Pertanian di Desa Sidoharjo

Dalam analisia kemampuan dan kebutuhan penyandang disabilitas dalam sektor pertanian di Desa Sidoharjo pada penelitian ini menggunakan teknik analisis yang sama dengan sasaran sebelumnya yaitu teknik analisis content. Analisis content memiliki tahapan-tahapan sebagai berikut :

1. Tahapan awal adalah pengunitan. Pengunitan adalah upaya untuk mengambil data yang dibutuhkan sesuai dengan kepentingan penelitian yang dapat diobservasi lebih lanjut.

2. Selanjutnya dilakukan sampling dengan membatasi jumlah stakeholders yang menjadi sumber data. Stakeholders telah ditentukan sebelumnya melalui analisis stakeholder dimana telah mewakili karakteristik populasinya.

3. Berikutnya dilakukan perekaman atau pengkodean untuk menjembatani antara teks dengan peneliti. Dalam pengodean, dicermati pernyataan-pernyataan yang merepresentasikan suatu makna yang terkait dengan tujuan yang diharapkan yaitu indikasi relevan dari suatu variabel.

4. Tahapan selanjutnya dilakukan pemahaman data terhadap tiap unit analisis untuk melihat relevansinya. Sehingga dapat menjembatani dalam penarasian karakteristik unit, sehingga dapat disimpulkan konsensusnya.

5. Pada tahapan akhir adalah penarasian dari hasil analisis.

F. Perumusan Arahan Pengembangan Desa Tertinggal Kabupaten Bondowoso Berdasarkan Aspek-Aspek yang diprioritaskan menggunakan Analisis Deskripti Narasi

Dalam penentuan alternatif pemanfaatan penyandang disabilitas bagi kegiatan pertanian di Desa Sidoharjo, digunakan teknik analisis triangulasi. Triangulasi adalah istilah teknik analisis yang merujuk pada penggabungan berbagai metode dalam suatu kajian tentang suatu gejala tertentu. Ada beberapa aspek yang menjadi acuan konsep triangulasi. Sumber informasi dapat didapatkan dari pakar yang kompeten, peneliti sendiri, dan atau wacana empiric [6].
Tujuan dari triangulasi sendiri adalah mencari prioritas, intervensi dan jalan keluar dari semua pihak. Namun, tentu dalam mencapai tujuan tersebut, perumusan bersama-sama untuk mencapai pilihan yang terbaik merupakan konflik tersendiri karena analisa ini berangkat dari teknik pertisipatif. Sedangkan alat analisis yang dapat berupa kuisioner, wawancara, dan studi literatur dari pengalaman empirik di tempat lain. Validasi dilakukan dengan terakomodasinya ketiga sumber informasi menjadi pemecahan masalah yang terbaik menurut peneliti.

\section{HASIL DAN DISKUSI}

\section{A. Identifikasi Potensi Pertanian di Desa Sidoharjo}

Berdasarkan hasil tinjauan pustaka didapatkan aspek-aspek yang merupakan indikator potensi pertanian adalah :

a. Aspek Usaha Tani

Aspek usaha tani terdiri dari variabel produk pertanian dan teknologi pertanian.

b. Aspek Kegiatan Pertanian

Aspek kegiatan pertanian terdiri dari variabel kegiatan budidaya, kegiatan panen, dan kegiatan pascapanen.

Berikut ini merupakan hasil identifikasi potensi pertanian di Desa Sidoharjo menggunakan analisis content.

1. Potensi Produk Pertanian

Berdasarkan hasil analisis terdapat 17 potensi produk atau komoditas pertanian di Desa Sidoharjo. Tujuh belas komoditas tersebut terbagi atas tanaman pangan dan tanaman hortikultura. Potensi tanaman pangan di Desa Sidoharjo adalah jagung, ketela, kacang tanah, dan kacang hijau. Sedangkan potensi tanaman hortikultura di Desa Sidoharjo adalah tomat, brokoli, cabe, kol dataran rendah, sawi, buncis, mentimun, kacang panjang, pepaya, jeruk, melon, kelengkeng, dan nangka cempedak.

\section{Potensi Teknologi Pertanian}

Berdasarkan hasil analisis terdapat 10 potensi teknologi pertanian di Desa Sidoharjo. Sepuluh potensi teknologi pertanian di Desa Sidoharjo antara lain : okulasi granting, pembuahan di depan musim, penggunaan pupuk organik beserta pupuk anorganik, trip irigation, plastik perak HDP, penyiapan lahan menggunakan dolomit beserta pupuk kandang organik, penyiapan lahan menggunakan traktor, pemompaan air sungai untuk pengairan, benih hibrida, dan penggunaan mesin pipil.

3. Potensi Kegiatan Budidaya

Berdasarkan hasil analisis terdapat 11 kegiatan pertanian di Desa Sidoharjo yang termasuk kegiatan budidaya. Kegiatan-kegiatan tersebut adalah penyiapan lahan; penyiapan bibit; pemberian plastik perak HDP; penanaman bibit; pengendalian hama, gulma, dan penyakit; perawatan fisik, penyiangan, pendangiran, pengikatan keturus dan palang; pemupukan; dan pengairan.

4. Potensi Kegiatan Panen

Berdasarkan hasil analisis dalam potensi kegiatan panen hanya ada kegiatan panen secara umum.

\section{Potensi Kegiatan Pascapanen}


Berdasarkan hasil analisis terdapat 12 kegiatan pertanian yang termasuk potensi kegiatan pascapanen. Kegiatan-kegiatan tersebut antara lain: sortasi, grading, pengupasan, pencucian, pemipilan, penjemuran, penumbukkan, pengepakan, pengangkutan, penyimpanan, pemasaran, dan pembersihan lahan.

Berdasarkan 17 potensi produk pertanian di Desa Sidoharjo, kemudian dipilih produk atau komoditas pertanian yang dapat dibudidayakan oleh penyandang disabilitas di Desa Sidoharjo. Produk pertanian yang dapat dibudidayakan oleh penyandang disabilitas di Desa Sidoharjo adalah tanaman pangan, antara lain: jagung, ketela, kacang tanah, dan kacang hijau.

Selanjutnya, dari keempat komoditas pertanian tersebut didapatkan kegiatan-kegiatan yang sesuai. Terdapat 17 kegiatan pertanian yang sesuai dengan tanaman-tanaman tersebut, antara lain: pengadaan bibit, penyiapan lahan, penanaman bibit, pemupukan, penyiangan, pendangiran, perlindungan dari hama dan penyakit, pemanenan, sortasi, pengupasan, penjemuran, pemipilan, penumbukkan, pengepakan, pengangkutan, pembersihan lahan dan pemasaran.

\section{B. Analisia Kemampuan dan Kebutuhan Penyandang} Disabilitas dalam Sektor Pertanian di Desa Sidoharjo

Analisa kemampuan dan kebutuhan penyandang disabilitas dalam sektor pertanian memiliki tiga bahasan pokok yaitu karakteristik penyandang disabilitas di Desa Sidoharjo, kemampuan penyandang disabilitas di Desa Sidoharjo, dan kebutuhan penyandang disabilitas di Desa Sidoharjo.

Bahasan pertama adalah karakteristik penyandang disabilitas di Desa Sidoharjo yang terdiri atas dua variabel yaitu penyebab kedisabilitasan dan kebiasaan sehari-hari penyandang disabilitas. Berdasarkan hasil analisis, ditemukan 6 faktor penyebab kedisabilitasan di Desa Sidoharjo, antara lain:

1. Kurang gizi

2. Pelayanan kesehatan yang kurang memadai

3. Sanitasi yang buruk

4. Gen turunan dari penyandang disabilitas

5. Pernikahan dini

6. Kelahiran yang tidak dikehendaki

Faktor pertama dan keempat sesuai, serta faktor kelima dan keenam jika ditarik lebih jauh maka juga sesuai penjelasan Wardhani yang membagi penyebab kedisabilitasa berdasarkan masa terjadinya dan agen pembawa kelainan. Berdasarkan masa terjadinya, penyebab kedisabilitasa dibagi atas pranatal, perinatal, dan postnatal [7].

Sedangkan untuk karakteristik kebiasaaan sehari-hari penyandang disabilitas di Desa Sidoharjo, berdasarkan hasil analisis didapatkan bahwa penyandang tunanetra, penyandang tunarungu wicara, penyandang tunagrahita tingkat ringan, dan penyandang tunagrahita tingkat sedang memiliki kebiasaan sehari-hari yang hampir sama seperti manusia normal pada umumnya. Ciri khusus dari penyandang tunanetra adalah mata yang tidak dapat melihat. Ciri khusus dari penyandang tunarungu wicara adalah penggunaan mutlak bahasa isyarat saat berkomunikasi. Ciri khusus dari penyandang tunagrahita tingkat ringan adalah cara berpakaian yang kurang rapi, perilaku yang terlihat kurang sehat, dan kurang menyambung dalam berkomunikasi. Ciri khusus dari penyandang tunagrahita tingkat sedang adalah cara berpakaian yang kurang rapi, perilaku yang terlihat kurang sehat, kurang menyambung dalam berkomunikasi, serta harus ada perintah dari orang lain jika ingin melakukan sesuatu (tingkat kemandirian yang rendah). Sedangka penyandang tunagrahita tingkat berat memiliki kebiasaan sehari-hari yang sangat kontras berbeda dari orang normal maupun penyandang disabilitas yang lain. Kebiasaan sehari-hari penyandang tunagrahita tingkat berat adalah berdiam di rumah. Hal ini diakibatkan kepada ketidak mampuan penyandang tunagrahita tingkat berat dalam melakukan kegiatan umum sehari-hari dalam perspektif manusia normal.

Bahasan kedua adalah kemampuan penyandang disabilitas di Desa Sidoharjo yang terdiri atas variabel kemampuan belajar dan kemampuan bekerja dalam sektor pertanian. Berdasarkan hasil analisis mengenai kemampuan belajar panyandang disabilitas di Desa Sidoharjo didapatkan bahwa jenis penyandang disabilitas yang termasuk dalam kategori educable atau mampu ajar adalah penyandang tunanetra, penyandang tunarungu wicara, dan penyandang tunagrahita tingkat ringan. Penyandang disabilitas di Desa Sidoharjo yang termasuk dalam kategori trainable atau mampu latih adalah penyandang tunagrahita tingkat sedang. Sedangkan penyandang disabilitas di Desa Sidoharjo yang termasuk dalam kategori totally dependent adalah penyandang tunagrahita tingkat berat.

Sehingga dapat proses pendidikan lebih lanjut, penyandang tunanetra, penyandang tunarungu wicara, dan penyandang tunagrahita ringan dapat menempuh pendidikan formal maupun pelatihan yang dapat membantu dalam mengembangkan potensi dalam berpikir dan berketerampilan. Sedangkan penyandang tunagrahita sedang yang masuk dalam kategori trainable maka secara umum akan kesulitan untuk menyesuaikan diri dengan pendidikan formal yang berbasis kepada hafalan dan olah pemikiran. Pendidikan bagi penyandang tunagrahita sedang lebih sesuai dengan pendidikan yang berbasis pelatihan dan keterampilan yang dapat dilakukan secara berulang-ulang. Kemudian, untuk penyandang tunagrahita berat akan sangat kesulitan untuk menjalani proses pendidikan, baik formal dengan basis olah pemikiran, maupun pelatihan dengan basis olah keterampilan.

Selanjutnya, kemampuan bekerja penyandang disabilitas dalam sektor pertanian difokuskan kepada 17 kegiatan pertanian yang berkaitan dengan tanaman pangan karena penyandang disabilitas di Desa Sidoharjo yang bergerak dalam sektor pertanian umumnya membudidayakan tanaman pangan. Kegiatan-kegiatan pertanian yang tersebut antara lain:

1. penyiapan lahan,

2. pengadaan bibit,

3. penanaman bibit,

4. pemupukan,

5. penyiangan, 
6. pendangiran,

7. perlindungan dari hama dan penyakit,

8. pemanenan,

9. sortasi,

10. pengupasan,

11. penjemuran,

12. pemipilan,

13. penumbukan,

14. pengepakan,

15. pengangkutan,

16. pemasaran, dan

17. pembersihan lahan.

Hasil analisa kemampuan penyandang disabilitas dalam sektor pertanian adalah sebagai berikut:

\section{Penyandang Tunanetra}

Beberapa jenis kegiatan pertanian yang mampu dilakukan secara mandiri antara lain: penyiapan lahan, pemupukan, penyiangan, pendangiran, sortasi, pengupasan, penjemuran, pemipilan, penumbukan, dan pengepakan. Beberapa kegiatan yang mampu dilakukan dengan syarat antara lain: pengadaan bibit, penanaman bibit, pemanenan, dan pemasaran Sedangkan jenis kegiatan pertanian yang tidak mampu dilakukan antara lain: perlindungan dari hama dan penyakit; pengangkutan; dan pembersihan lahan.

\section{Penyandang Tunarungu wicara}

Beberapa jenis kegiatan yang dapat dilakukan secara mandiri oleh penyandang tunarungu wicara antara lain: penyiapan lahan, penanaman bibit, pemupukan, penyiangan, pendangiran, perlindungan dari hama dan penyakit, pemanenan, sortasi, pengupasan, penjemuran, pemipilan, penumbukan, pengepakan, pengangkutan, dan pembersihan lahan. Sedangkan jenis kegiatan yang tidak mampu dilakukan oleh penyandang tunarungu wicara adalah pengadaan bibit dan pemasaran.

\section{Penyandang Tunagrahita Tingkat Ringan}

Kegiatan-kegiatan yang mampu dilakukan secara mandiri antara lain: penyiapan lahan, penanaman bibit, pemupukan, penyiangan, pendangiran, perlindungan dari hama dan penyakit, pemanenan, sortasi, pengupasan, penjemuran, pemipilan, penumbukan, pengepakan, pengangkutan, dan pembersihan lahan. Sedangkan kegiatan-kegiatan yang masuk kategori mampu dengan syarat adalah pengadaan bibit dan pemasaran.

\section{Penyandang Tunagrahita Tingkat Sedang}

Beberapa jenis kegiatan yang dapat dilakukan dengan syarat oleh penyandang tunagrahita tingkat sedang antara lain: penyiapan lahan, penanaman bibit, pemupukan, penyiangan, pendangiran, perlindungan dari hama dan penyakit, pemanenan, sortasi, pengupasan, penjemuran, pemipilan, penumbukan, pengepakan, pengangkutan, dan pembersihan lahan.

\section{Penyandang Tunagrahita Tingkat Berat}

Penyandang tunagrahita tingkat berat tidak mampu bekerja dalam semua kegiatan dalam pertanian. Hal ini disebabkan kemampuan intelegensia yang rendah dari penyandang tunagrahita sehingga juga menyebabkan kemampuan kognitif dan psikomotorik juga rendah. Dengan kemampuan-kemampuan tersebut yang rendah maka penyandang tunagrahita akan mengalami kesulitan dalam beraktivitas termasuk bekerja dalam bidang pertanian.

Bahasan ketiga adalah kebutuhan penyandang disabilitas di Desa Sidoharjo yang terbagi atas kebutuhan umum dan kebutuhan bidang pertanian. Berdsarkan hasil analisis, tidak semua jenis penyandang disabilitas membutuhkan kebutuhan yang bersifat umum. Jenis disabilitas yang dianjurkan untuk dibantu dengan kebutuhan yang bersifat umum adalah penyandang tunarungu wicara. Bentuk kebutuhan umum adalah alat bantu komunikasi dengan contoh alat bantu dengar. Dengan bantuan ini diharapkan agar memudahkan penyandang tunarungu wicara dalam berkomunikasi, mendapat informasi, serta mendapat arahan sehingga penyandang tunarungu wicara dapat lebih produktif dan lebih cepat beraksi.

Sedangkan untuk kebutuhan pertanian pertanian bagi penyandang disabilitas di Desa Sidoharjo berdasarkan hasil analisis, antara lain: benih atau bibit, pupuk, peralatan pertanian, palatihan dan pembinaan.

\section{Alternatif Pemanfaatan Penyandang Disabilitas bagi Kegiatan Pertanian di Desa Sidoharjo}

Alternatif pemanfaatan penyandang disabilitas bagi kegiatan pertanian di Desa Sidoharjo menggunakan teknik analisis triangulasi. Terdapat tiga sumber yang diperbandingkan dalam analisis ini, yaitu hasil analisis 1 dan 2 yang berkaitan dengan potensi produk pertanian di Desa Sidoharjo, kemampuan penyandang disabilitas di Desa Sidoharjo dalam bidang pertanian, kebutuhan penyandang disabilitas di Desa Sidoharjo dalam bidang pertanian; tinjauan pustaka terkait; serta tinjauan kebijakan terkait.

Hasil analisis mengenai alternatif pemanfaatan penyandang disabilitas bagi kegiatan pertanian di Desa Sidoharjo antara lain: penelitian, alternatif pemanfaatan penyandang disabilitas yaitu 1) menfokuskan pembudidayakan tanaman pangan bagi penyandang disabilitas, 2) melakukan riset tanaman alternatif untuk dibudidayakan oleh penyandang disabilitas, 3) memberikan penyuluhan atau pemberian informasi kegiatan pertanian yang direkomendasikan, diperboleh dengan syarat, dan tidak disarankan bagi penyandang disabilitas, 4) membentuk jaringan kerja untuk penyandang disabilitas, 5) melakukan habilitasi dan rehabilitasi kepada penyandang disabilitas terutama yang memiliki potensi namun tidak aktif dan produktif, 6) melakukan resosialisasi kepada masyarakat, 7) pemberian pembinaan dan pelatihan kepada penyandang disabilitas dalam bidang pertanian, 8) penyediaan aksesbilitas yang ramah disabilitas di lokasi maupun akses menuju lokasi tempat transaksi sarana produksi pertanian, 9) penyediaan peralatan pertanian yang variatif dan menyesuaikan dengan keadaan penyandang disabilitas. 


\section{KESIMPULAN}

Pada penelitian ini bertujuan untuk merumuskan alternatif pemanfaatan penyandang disabilitas bagi kegiatan pertanian di Desa Sidoharjo. Berikut ini merupakan hasil yang diperoleh dari penelitian ini :

1. Potensi produk pertanian yang dapat budidayakan oleh penyandang disabilitas di Desa Sidoharjo adalah tanaman pangan, antara lain: jagung, ketela, kacang hijau, dan kacang tanah.

2. Penyandang tunanetra mampu secara mandiri melakukan kegiatan penyiapan lahan, pemupukan, penyiangan, pendangiran, sortasi, pengupasan, penjemuran, pemipilan, penumbukan, dan pengepakan. Penyandang tunarungu wicara mampu secara mandiri melakukan kegiatan penyiapan lahan, penanaman bibit, pemupukan, penyiangan, pendangiran, perlindungan dari hama dan penyakit, pemanenan, sortasi, pengupasan, penjemuran, pemipilan, penumbukan, pengepakan, pengangkutan, dan pembersihan lahan. Penyandang tunagrahita ringan mampu secara mandiri melakukan kegiatan penyiapan lahan, penanaman bibit, pemupukan, penyiangan, pendangiran, perlindungan dari hama dan penyakit, pemanenan, sortasi, pengupasan, penjemuran, pemipilan, penumbukan, pengepakan, pengangkutan, dan pembersihan lahan. Penyandang tunagrahita sedang mampu bersyarat melakukan kegiatan penyiapan lahan, penanaman bibit, pemupukan, penyiangan, pendangiran, perlindungan dari hama dan penyakit, pemanenan, sortasi, pengupasan, penjemuran, pemipilan, penumbukan, pengepakan, pengangkutan, dan pembersihan lahan.

3. Alternatif pemanfaatan penyandang disabilitas bagi kegiatan pertanian di Desa Sidoharjo antara lain: menfokuskan pembudidayakan tanaman pangan bagi penyandang disabilitas; melakukan riset tanaman alternatif untuk dibudidayakan oleh penyandang disabilitas; memberikan penyuluhan atau pemberian informasi kegiatan pertanian yang direkomendasikan, diperboleh dengan syarat, dan tidak disarankan bagi penyandang disabilitas; membentuk jaringan kerja untuk penyandang disabilitas; melakukan habilitasi dan rehabilitasi kepada penyandang disabilitas; melakukan resosialisasi kepada masyarakat; pemberian pembinaan dan pelatihan kepada penyandang disabilitas dalam bidang pertanian; penyediaan aksesbilitas yang ramah disabilitas di lokasi maupun akses menuju lokasi tempat transaksi sarana produksi pertanian; penyediaan peralatan pertanian yang variatif dan menyesuaikan dengan keadaan penyandang disabilitas.

\section{DAFTAR PUSTAKA}

[1] Badan Pusat Statistik Kabupaten Ponorogo, "Kabupaten Ponorogo dalam Angka 2016.," Ponorogo, 2017.

[2] Badan Pusat Statistik Kabupaten Ponorogo, "Kecamatan Jambon dalam Angka 2016," Ponorogo, 2017.

[3] B. Bungin, Metode Penelitian Kualitatif. Jakarta: Rajawali Pers, 2010.

[4] L. Moleong, Metodologi Penelitian Kualitatif. Bandung: Remaja Rosdakarya, 2004.

[5] K. Krippendorff, Content Analysis an Introduction to its Metodology, 2nd ed. London: Sage Publications, 2004.

[6] D. Sugiyono, Metode Penelitian Bisnis. Bandung: Pusat Bahasa Depdiknas, 2008.

[7] I.G.A.K. and Wardhani, Pengantar Pendidikan Anak Berkebutuhan Khusus. Tangerang: Universitas Terbuka, 2013. 